\title{
NILAI BUDAYA TANAM PADI SEBAGAI DAYA TARIK WISATA
}

Didin Syarifuddin

ARS Internasional School of Tourism, Bandung, Indonesia, email: didinars123@gmail.com

\begin{abstract}
ABSTRAK
Histori Artikel

Submitted:

26 September 2020

Reviewed:

1 Oktober 2020

Accepted:

14 Oktober 2020

Published:

15 November 2020

Jawa Barat merupakan sentra produksi padi Indonesia, yang berkontribusi sebesar 16 persen produksi padi nasional. Namun keunggulan tersebut belum berkontribusi terhadap penumbuhan kesadaran generasi muda untuk melestarikan budaya tanam padi. Atas dasar permasalahan tersebut maka tujuan penelitian ini adalah untuk menjelaskan bagaimana nilai budaya tanam padi dengan daya tarik wisatanya pada masyarakat Kampung Adat Cikondang. Metode penelitian yang digunakan adalah metode kualitatif, melalui wawancara mendalam dan kelompok, dengan analisis data reduksi dan penyajian data. Hasil penelitian menunjukkan bahwa prosesi tanam padi sarat dengan nilai budaya serta memiliki daya tarik wisata. Nilai tersebut tergambar dari nilai hakikat manusia, hakikat hubungan manusia dengan alam sekitar, hakikat kedudukan manusia dalam ruang dan waktu, hakikat hubungan manusia dengan karya dan beramal dan hakikat hubungan manusia dengan manusia lain. Sementara daya tarik wisatanya tergambar dari keunikan, kemenarikan, kelangkaan, keaslian, kebersihan dan keamanan.
\end{abstract}

Kata Kunci: Nilai, nilai budaya, daya tarik wisata

\section{THE VALUE OF RICE PLANTING CULTURE AS TOURISM INTEREST}

\begin{abstract}
West Java is the center of Indonesian rice production, which contributes 16 percent of the national rice production. However, these advantages have not contributed to the growing awareness of the younger generation to preserve the rice planting culture. On the basis of these problems, the purpose of this study is to explain how the cultural value of rice planting with the tourist attraction of the Cikondang Traditional Village community. The research method used is a qualitative method, through in-depth interviews and groups, with data reduction analysis and data presentation. The results showed that the rice planting procession was loaded with cultural values and had a tourist attraction. This value is reflected in the value of human nature, the nature of human relations with the surrounding environment, the essence of human position in space and time, the essence of human relations with work and charity and the nature of human relations with other humans. Meanwhile, the attraction of the tour is reflected in the uniqueness, attractiveness, rarity, authenticity, cleanliness and safety.
\end{abstract}

Key Words: Value, Cultural Value, Tourist Attraction

\section{PENDAHULUAN}

Jawa Barat merupakan kumpulan berbagai jenis alam yang sangat indah dengan daya tarik budaya yang sangat mempesona (Syarifuddin, 2017). Daya tarik budaya ditunjukkan melalui keanekaragaman buah karyanya sebagai hasil proses budaya baik berupa nilai, norma, adat maupun karya seni (Syarifuddin, 2020). Berbicara keindahan alam yang dikuatkan oleh keanekaragaman buah karya yang memiliki nilai daya tarik budaya, maka akan berkaitan dengan aspek 
kepariwisataan. Atas dasar hal tersebut maka Jawa Barat layak menjadi bagian penting dalam kegiatan kepariwisataan di Indonesia, bahkan di Dunia (Syarifuddin \& Priyanto, 2020).

Kondisi dunia pariwisata saat ini, tidak lagi menjadi sektor usaha primadona dalam menghasilkan devisa negara, sebagai dampak dari pandemi Covid-19 (Syarifuddin, 2020). Pandemi Covid 19 yang diikuti resesi dunia juga berdampak terhadap ketersediaan pangan sebagai kebutuhan mendasar, sehingga menjadikan negara-negara di dunia lebih mementingkan ketersediaan pangan ini bagi warganya agar terhindar dari kondisi kelaparan (Solihat, Kodar, Pikiran Rakyat, 19 Oktober 2020). Hal inipun menjadi bagian penting bagi Provinsi Jawa Barat untuk terhindar dari kekurangan pangan, lebih lagi daerah ini tetap diunggulkan untuk menjadi sentra produksi padi di Indonesia.

Rumpun agro memegang peranan vital terkait penyediaan pangan, termasuk di Indonesia (Solihat, Kodar, Pikiran Rakyat, 19 Oktober 2020). Sektor pertanian akan menjadi salah satu andalan utama untuk pemulihan ekonomi Jawa Barat, pada tahun 2021. Sebab sektor pertanian terbukti menjadi satu dari dua usaha (besama teknologi informasi) yang tetap tumbuh pada saat krisis ekonomi akibat pandemik Covid19. (Pikiran Rakyat, Tajuk Rencana, Petani Sejahtera 2020). Salah satu cara yang dapat dilakukan adalah meningkatkan minat generasi muda untuk terjun dan menekuni rumpun usaha pertanian (Pikiran Rakyat, Tajuk Rencana, Petani Sejahtera 2020).

Sektor pertanian sudah teruji dan terbukti paling tahan banting saat krisis ekonomi dan terbukti menjadi sektor andalan. Oleh karena itu, sektor usaha rumpun pertanian harus menjadi salah satu perhatian utama pembangunan ekonomi Jawa Barat, dengan harapan membawa daya tarik yang besar bagi generasi milenial. (Pikiran Rakyat, Tajuk Rencana, Petani Sejahtera 2020).

Sebenarnya, sejak sekitar tiga tahun terakhir minat usaha pertanian di Indonesia bermunculan di kalangan muda. Namun hal ini hanya terjadi pada sebagian sub sektor usaha lingkup agro yaitu holtikultura, perikanan, perkebunan serta kehutanan. Lain halnya untuk sektor tanaman pangan, terutama padi, sampai kini belum muncul petani generasi muda, karena belum bisa memberikan peningkatan kesejahteraan bagi para petaninya (Solihat, Kodar, Pikiran Rakyat, 19 Oktober 2020).

Apa yang terjadi dengan rendahnya minat kalangan muda dalam sektor tanaman padi di Jawa Barat, juga terjadi pada kalangan muda di Kampung Adat Cikondang, Kabupaten Bandung. Hal ini tidak sesuai dengan prestasi Jawa Barat dalam penyedia bahan pangan nasional yang telah menunjukkan keberhasilannya dalam produksi padi nasional karena merupakan salah satu sentra produksi padi di Indonesia yang memberikan kontribusi besar terhadap produksi beras nasional, yaitu sekitar 16 persen terhadap produksi padi nasional. (Dinas Pertanian Tanaman Pangan, 2011).

Kampung Adat Cikondang secara administratif berada dalam wilayah Desa Lumajang, Kecamatan Pangalengan, Kabupaten Bandung, Provinsi Jawa Barat. Kampung Adat Cikondang sangat kental dengan kearifan budaya lokal salah satunya adalah upacara tanam padi. Kearifan lokal pada upacara tanam padi ini telah dikenal luas oleh para wisatawan, karena menjadi bagian penting dalam kehidupan masyarakat yang bernilai sosial tinggi, seperti nilai kerjasama, nilai gotong royong, dan nilai sukarela. Nilai-nilai inilah yang relatif sudah tidak ditemui di hampir sebagian besar Wilayah Jawa Barat dalam kegiatan tanam dan panen padi. Hal lain adalah bahwa tingginya tingkat apresiasi wisatawan terhadap nilai-nilai yang terkandung dalam kegiatan prosesi tanam padi tidak dibarengi dengan tingginya minat masyarakat, khususnya di kalangan pemuda dalam melestarikan budaya tanam padi ini.

Budaya tanam padi di Kampung Adat Cikondang dengan nilai-nilai sosial dan budaya yang terkandung di dalamnya, telah menjadi sebuah model daya tarik wisata minat khusus bagi para wisatawan. Minat khusus pada daya tarik wisata ini, karena 
dapat memberikan pengalaman baru bagi wisatawan, wisatawan dapat belajar tentang lingkungan setempat, dapat menikmati kebudayaan lokal, dan terutama para wisatawan dapat menjalin kontak langsung yang lebih dekat dengan masyarakat setempat (Ridho, 2014). Wisata minat khusus ini tidak lain adalah wisata budaya yang relatif sangat berkembang di Indonesia (Nafila, 2013). Wisata budaya adalah salah satu pariwisata yang menjadikan budaya sebagai daya Tarik wisata.

Tujuan wisatawan mengunjungi wisata budaya yaitu untuk memahami hakikat dan membandingkannya dengan kondisi wisata budaya yang dimilikinya sebagai sebuah pengalaman baru, dan tentunya di samping nilai dan filosofi di dalamnya (Prasodjo, 2017). Salah satu kebudayaan yang dapat dijadikan daya tarik wisata adalah agrowisata tanam padi.

Bertolak dari penjelasan dalam latar belakang penelitian, maka penulis menganggap perlu untuk melakukan penelitian dan menetapkan tema dengan judul "Nilai Budaya Tanam padi pada Masyarakat Kampung Adat Cikondang Sebagai Daya Tarik Wisata".

\section{LITERATUR REVIEW Nilai Budaya}

Nilai adalah esensi yang melekat pada sesuatu yang sangat berarti bagi kehidupan manusia, karena dapat memberikan manfaat bagi manusia dan dapat dijadikan acuan bagi masyarakat di dalam berperilaku (M. Chabib Thoha, 1996). Ini artinya bahwa nilai akan berkaitan dengan hal-hal penting yang berguna bagi kemanusiaan (W.J.S. Purwadarminta, 1999). Nilai adalah sesuatu yang bersifat abstrak, ideal, nilai bukan benda konkrit, bukan fakta, tidak hanya persoalan benar dan salah yang menuntut pembuktian empirik, melainkan soal penghayatan yang dikehendaki, disenangi, dan tidak disenangi (Mansur Isna, 2001). Nilai merupakan suatu hal yang diyakini dalam lingkup sistem kepercayaan bagaimana seorang bertindak atau menghindari suatu tindakan. (H. Una Kartawisastra, 1980). Nilai terletak pada esensi objek yang dituju yang menjadi kepentingan masyarakat dan nilai diciptakan oleh situasi kehidupan (Syamsul Maarif, 2007).

Dari beberapa pengertian yang disampaikan tersebut, dapat disimpulkan bahwa: (1) Nilai bersifat abstrak, ideal, bukan fakta, tidak hanya berbicara benar dan salah, membutuhkan adanya penghayatan yang dikehendaki; (2) Nilai berguna dan bermanfaat bagi masyarakat; (3) Nilai dapat dijadikan sebagai acuan tingkah laku, apakah seseorang melakukannya atau menghindarinya; (4) Nilai diyakini dalam ruang lingkup sistem kepercayaan; (5) Nilai tidak perlu sama di masyarakat, karena masyarakat memiliki karakteristik yang berbeda pada aspek sosiologis, ekonomis, kepercayaan, dan sebagainya; (6) Nilai ditanamkan, artinya nilai yang lahir di masyarakat sebagai hasil dari proses penanaman dari generasi sebelumnya kepada generasi berikutnya; (7) Nilai adalah sesuatu yang dianggap penting bagi kehidupan masyarakat, kerena pentingnya nilai ini maka masyarakat menjadikannya sebagai acuan dalam berinteraksi sosial di masyarakat; (8) Sesuatu dianggap bernilai kalau masuk dalam pola tingkah laku dan pola fikir kelompok; (9) Nilai diakui bersama dalam kelompok.

Nilai budaya terdiri dari konsepsi-konsepsi yang hidup dalam alam fikiran sebagian besar warga masyarakat mengenai hal-hal yang mereka anggap sangat mulia (Koentjaraningrat, 1987). Sistem nilai yang ada dalam suatu masyarakat dijadikan orientasi dan rujukan dalam bertindak. Oleh karena itu, nilai budaya yang dimiliki seseorang akan menentukan alternatif, cara cara, alat - alat, dan tujuan - tujuan dari perilaku yang dilakukan orang tersebut (Syarifuddin, 2015).

Kluckhohn, (1954) menjelaskan "Conception of the contents of the system of cultural values, which are universally present in every culture in the world, gradually developed by $C$. and $F$. Kluckhohn. According to Kluckhohn and Strodtbeck, the questions of the most high value on human 
life and which exists in every culture in the world, involving at least five things": (1) Human nature, or the meaning of human life; (2) Man's nature, about the meaning of man's relationship with the natural surrounding; (3) Time, human perception of time; (4) Activity, about the meaning of work, work and charitable deeds; dan (5) Relational, man's relationship with fellow human beings C. Kluckhohn, (1954) menyampaikan nilai budaya dalam penjelasan konsep isi tentang sistem nilai budaya yang bersifat universal yang ada di setiap budaya di dunia, sebagai nilai yang paling tinggi dalam kehidupan manusia, meliputi sedikitnya terdapat lima hal, yaitu: (1) Hakikat Manusia. Berkaitan dengan sifat manusia pada aspek hakikat manusia dapat dijelaskan dalam (a) pandangan bahwa hidup itu buruk, mereka yang penuh frustrasi dalam kehidupannya; (b) pandangan bahwa hidup itu baik, mereka yang beranggapan bahwa hidup itu tidak dapat diubah, terima apa adanya; (c) pandangan bahwa hidup itu penuh dengan kesulitan, mereka yang beranggapan bahwa hidup itu harus diperjuangkan; (2) Hakikat Hubungan Manusia dengan Alam Sekitar. Berkaitan dengan sifat manusia untuk melihat makna hubungan manusia dengan alam sekitarnya, dalam (a) pandangan bahwa hidup itu harus tunduk kepada alam, artinya menerima apa adanya terhadap apa yang terjadi; (b) pandangan bahwa hidup itu harus selaras dengan alam, artinya harus mengikuti waktu yang baik ketika akan beraktivitas; (c) pandangan bahwa manusia hidup harus menguasai alam, sehingga manusia harus memiliki ilmu untuk mengantisipasi terhadap kejadian alam bahkan bagaimana mengembangkannya; (3) Hakikat Kedudukan Manusia dalam Ruang dan Waktu. Berkaitan dengan sifat manusia hubungannya dengan ruang dan waktu, dalam (a) pandangan bahwa manusia hidup harus berorientasi ke masa lalu, mereka yang berpandangan bahwa masa lalunya sebagai standar kebijakan kepada anaknya; (b) pandangan bahwa manusia hidup harus berorientasi ke masa kini, artinya keputusan yang harus diambil atas dasar kepentingan saat ini; (c) pandangan bahwa manusia hidup harus berorientasi ke masa depan, artinya keputusan yang diambil sekarang harus atas dasar kepentingan anak cucu dimasa yang akan datang; (4) Hakikat Hubungan Manusia dengan Karya. Berkaitan dengan sifat manusia untuk melihat persepsi manusia terhadap karya dan beramal; (a) pandangan bahwa hidup manusia hanya atas dasar keberlangsungan hidup, artinya melakukan sesuatu dengan tujuan bisa hidup; (b) pandangan bahwa hidup manusia didasarkan pada kedudukan atau kehormatan, artinya hidup untuk mendapatkan penghargaan dari orang-orang sekitar; (c) pandangan bahwa hidup manusia didasarkan pada bagaimana mempertinggi prestise, artinya bahwa manusia bekerja untuk beramal, menolong orang lain yang kurang beruntung atau untuk menghasilkan karya-karya besar; dan (5) Hakikat Hubungan Manusia dengan Manusia. Berkaitan dengan hakikat ini bahwa (a) pandangan bahwa hidup manusia harus hubungan vertikal, artinya hidup berorientasi ke atas menggambarkan senioritas; (b) pandangan bahwa hidup manusia bersifat horizontal atau kolekial, bahwa hidup membutuhkan orang lain, sehingga tumbuh sikap gotong royong saling membantu; (c) pandangan bahwa hidup manusia bersifat individual, artinya setiap manusia secara individu dituntut untuk menunjukkan prestasi atas apa yang telah dilakukannya.

Berdasarkan uraian di atas dapat disimpulkan bahwa nilai budaya merupakan nilai yang mengatur keseimbangan, keselarasan dan keserasian kehidupan manusia yang dijadikan rujukan dalam bertindak yang dapat mempengaruhi perilaku dalam memaknai hakikat hidup, hakikat hubungan manusia dengan alam sekitar, hakikat kedudukan manusia dalam ruang dan waktu, hakikat hubungan manusia dalam karya dan beramal bagi orang lain, serta hakikat hubungan manusia dengan manusia yang lain. Kelima aspek inilah yang menjadi alat analisis dalam penelitian ini. 


\section{Daya Tarik Wisata}

Daya tarik wisata yang dibangun oleh aspek keunikan, kemudahan, keanekaragaman kekayaan alam budaya, nilai sosial dan hasil buatan manusia serta nilai yang menjadi keinginan wisatawan untuk datang ke suatu destinasi dengan harapan mendapatkan kesenangan, kenyamanan, keindahan, dan kebersihan merupakan faktor utama yang menjadi pendorong kehadiran wisatawan ke suatu destinasi wisata (Syarifuddin, 2020). Daya tarik wisata adalah segala sesuatu yang memiliki keunikan, keindahan dan nilai yang berupa keanekaragaman budaya dan hasil buatan manusia yang menjadi sasaran atau tujuan kunjungan wisata (Undang-Undang Republik Indonesia,

Tentang Kepariwisataan, Nomor 10, 2009). Daya tarik wisata adalah segala sesuatu yang menjadi pemicu kunjungan wisatawan dapat berupa keaslian, keberagaman, keunikan, kemenarikan, kebersihan, dan keamanan di destinasi wisata (Warfani Suwardjokjo, 2007). Daya tarik wisata adalah sesuatu yang memiliki daya tarik untuk dilihat dan dinikmati yang layak dijual di pasar wisata (Zaenuri, 2012).

Berdasarkan uraian di atas dapat disimpulkan bahwa daya tarik wisata adalah segala sesuatu yang menjadi unsur daya tarik bagi wisatawan untuk datang ke suatu destinasi bisa berupa keunikan, kemudahan, keanekaragaman, keindahan, kemenarikan, keaslisan, kebersihan dan keamanan.

Syarifuddin (2020) menyatakan bahwa wisatawan tertarik untuk berkunjung ke suatu destinasi karena (1) Keunikan; (2) Keaslian; (3) Kemenarikan; (4) Kelangkaan, sulit ditemui di daerah atau negara lain; (5) Keberagaman; (6) Kebersihan; dan (7) Menumbuhkan semangat dan memberikan nilai bagi wisatawan.

Warfani Suwardjokjo, (2007) menyatakan bahwa faktor daya tarik yang menarik wisatawan, yaitu: (a) Keaslian adalah tampilan apa adanya dari lingkungan alam destinasi wisata; (b) Keberagaman adalah pemaduan antara daya tarik alami dengan daya tarik sosial budaya masyarakat setempat; (c) Keunikan adalah kekhasan yang hanya dimiliki oleh suatu destinasi wisata, dalam bentuk ketenangan lingkungan alam dan lingkungan sosial budaya, yang dapat menumbuhkan kenyamanan wisatawan; (d) Kemenarikan adalah lingkungan yang indah, cuaca yang menarik, bentang alam yang menantang, peninggalan sejarah yang merangsang keingintahuan, atau budaya yang unik dan peristiwa khusus; (e) Kebersihan adalah lingkungan yang bersih dan sehat, bebas pencemaran, bebas dari penyakit menular, lingkungan yang sejuk, segar, nyaman dan tetap tampil indah dalam keasliannya: (f) Keamanan adalah tumbuhnya perasaan aman bagi para wisatawan untuk melakukan berbagai aktivitas kepariwisataan.

Keenam faktor pendukung daya tarik wisata ini, dijadikan sebagai alat analisis secara teoritis dalam penelitian ini.

Berkaitan dengan penelitian ini indikator pendukung daya tarik wisata yang digunakan sebagai alat analisis adalah pada aspek keaslian, keberagaman, keunikan, kemenarikan, kebersihan, dan keamanan.

\section{METODE PENELITIAN}

Objek penelitian ini adalah budaya tanam padi dilihat dari aspek orientasi nilai budaya yang disampaikan oleh C. Kluckhohn, (1954) yang terdiri dari (1) Human nature, or the meaning of human life; (2) Man's nature, about the meaning of man's relationship with the natural surrounding; (3) Time, human perception of time; (4) Activity, about the meaning of work, work and charitable deeds; (5) Relational, man's relationship with fellow human beings. Metode penelitian yang digunakan adalah metode penelitian kualitatif dengan pendekatan etnografi. Metode ini menunjukkan bahwa informasi yang diperoleh atas dasar perspektif informan, yang diposisikan sebagai subjek penelitian. Data penelitian diperoleh melalui wawancara mendalam dan wawancara kelompok. Wawancara mendalam bertujuan untuk mendapatkan data primer mengenai nilai budaya tanam padi pada masyarakat Kampung Adat Cikondang. Sementara wawancara kelompok dilakukan dengan 
tujuan melakukan validitas data serta untuk mempertajam data hasil penelitian. Pengolahan dan analisis data dilakukan dengan reduksi dan penyajian data serta kesimpulan (Miles dan Huberman, 1984).

\section{HASIL DAN PEMBAHASAN}

\section{Prosesi Tanam Padi di Kampung Adat Cikondang}

Kegiatan tanam padi di Kampung Adat Cikondang dilakukan secara sukarela, karena hasil panen padi ini digunakan untuk kepentingan puncak upacara masyarakat. Masyarakat Kampung Adat Cikondang melakukan panen dua kali dalam satu tahun di dua lahan adat. Proses menanam padi terbagi menjadi tiga bagian, yang pertama, prosesi sebelum kegiatan tanam padi, dilanjutkan dengan prosesi tanam padi yang disebut tandur dan yang terakhir prosesi pasca pelaksanaan tanam padi.

Mencangkul. Mencangkul dilakukan oleh kaum laki-laki diatur dan diawasi oleh kuncen dengan menggunakan cangkul, garu, luku dan pohon pisang yang terjadi secara turun temurun dengan tunduk pada ketentuan waktu.

Tabur Benih. Tabur benih dilaksanakan di lahan yang berbeda, benih direndam sebelum ditabur, ditebarkan secara merata. Dalam kurun waktu 3-4 hari akan muncul kecambah padi, setelah kurang lebih tiga minggu tanaman padi muda siap dipindahkan ke sawah adat yang telah dicangkul.

Tanam Padi. Padi muda hasil tabur benih ditanam di sawah yang telah dicangkul. Kegiatan tanam padi dimulai dengan ritual membakar kemenyan, menanam jawer kotok, tamiang, dan hanjuang ditanam di aliran sumber mata air pesawahan ditambah rujak menemani bakaran kemenyan, serta mengacu pada waktu yang telah ditetapkan dengan tujuan mendapatkan hasil panen yang bagus yang prosesnya diawali oleh kuncen.

Panen Padi. Sebelum prosesi panen dimulai kuncen melaksanakan upacara ritual disaksikan oleh para wisatwan dan masyarakat, upacara ini dimulai dengan menyiapkan sesajen dalam sebuah wadah kayu berkaki lima yang diikat dapuran padi, yang berisi pisang, ketupat, tantang angin, dan wajit, setelahnya ditutup dengan kain kafan, selendang dan bendera merah putih setelah semua dipersiapkan kuncen mengelilingi pupuhunan sebanyak tiga kali. Padi di setiap arah di sekeliling pupuhunan tersebut diambil, lalu diikat mengguanakan daun sulangkar dan daun padi, jumlah padi pada ikatannya yaitu tujuh, setelah itu ikatan padi tersebut disisir dan dikepang, barulah kuncen berdoa sambil membakar kemenyan dan rokok. Setelah selesai berdoa, kuncen menentukan kemana arah mata angin dalam memanen dan mengumumkan kepada masyakarat yang akan panen padi ini. Setelah selesai kuncen memimpin upacara dan memberikan arahan kepada masyarakat untuk panen padi, maka masyarakat mulai melakukan panen padi dengan cara memotong padi menggunakan arit hingga seluruh padi yang ada di sawah adat terambil. Menumbuk Padi. Menumbuk padi masih dilakukan secara tradisional, dengan menggunakan lisung, sebagai warisan nenek moyang pendiri Kampung Adat Cikondang yang terbuat dari kayu dan telah berumur kurang lebih 300 tahun. Padi yang telah dipanen disimpan di sebuah bangunan panggung di lahan bumi adat yang disebut leuit, barulah di awal Bulan Muharam padi ini ditumbuk, seperti biasa, kegiatan menumbuk padi ini diawali oleh kuncen, lalu diikuti oleh para ibu-ibu dan diiringi dengan kesenian tradisional tarawangsa. Hal ini untuk menambah motivasi para ibu-ibu dalam melakukan penumbukan padi. Biasanya sebelum menumbuk padi, kaum ibu memainkan lisung dengan cara dipukulpukul sehingga terdengar irama suara lisung.

Nilai Budaya Tanam Padi Di Kampung Adat Cikondang

Hakikat Manusia

Kegiatan tanam padi di Kampung Adat Cikondang dilihat dari aspek hubungan manusia dengan kegiatan tanam padi, bagi sebagian kecil masyarakat, mereka beranggapan bahwa kegiatan tanam padi merupakan suatu kegiatan yang tidak dapat memberikan kesejahteraan bagi 
masyarakatnya, sehingga dianggap sebagai suatu kegiatan yang kurang produktif. Anggapan ini menyebabkan hilangnya rasa menghargai sampai pada hilangnya rasa ingin melestarikannya. Ini terjadi pada hampir sebagian besar masyarakat kalangan muda di Kampung Adat Cikondang.

Namun berbeda dengan mereka yang berpandangan bahwa kegiatan tanam padi merupakan anugrah dari Yang Maha Kuasa, sebagai suatu kebaikan yang harus diterima apa adanya. Tanam padi merupakan kegiatan sosial budaya masyarakat yang sifatnya turun temurun dengan nilai-nilai budaya yang terkandung di dalamnya, dimana masyarakat memiliki tanggung jawab untuk melestarikannya. Ini terjadi pada masyarakat yang meyakini pentingnya kegiatan tanam padi di Kampung Adat Cikondang dan harus dilakukan secara turun temurun.

Sementara terdapat masyarakat yang berpandangan lebih jauh ke depan, dengan melihat akibat yang ditimbulkannya apakah dapat memberikan manfaat maksimal bagi masyarakatnya atau hanya sebatas dapat mempertahankan hidup masyarakatnya. Masyarakat ini berpandangan bahwa kegiatan tanam padi merupakan kegiatan masyarakat dalam upaya mempertahankan hidupnya yang telah berjalan secara turun temurun dan dalam waktu yang sangat lama. Tanam padi memberikan pengajaran yang sangat tinggi bagi masyarakatnya, yaitu pengajaran pada aspek sosial yang penuh dengan nilai-nilai budaya di dalamnya, seperti nilai gotong royong, kerjasama, sukarela, dan banyak lagi nilai-nilai lain. Nilai-nilai inilah yang dapat merekatkan ikatan persaudaraan di antara masyarakat, sehingga menumbuhkan nilai empati, saling memberi, saling menghargai, saling menghormati, rasa menyayangi. Tumbuhnya masyarakat dengan menjadikan nilai-nilai sosial sebagai pegangan hidup masyarakatnya, menggambarkan tumbuhnya kehidupan yang penuh dengan keberkahan dan kebahagiaan. Namun, pada aspek lain masyarakat di Kampung Adat Cikondang dapat memanfaatkan aspek-aspek lain yang menjadi pendukung peningkatan percepatan keberhasilan dalam tanam padi, misalnya penggunaan teknologi yang ramah lingkungan dengan tetap memberdayakan masyarakat sebagai peran utamanya. Hal ini akan memberikan kemudahan dan peningkatan hasil produksi padi, dengan tetap memperhatikan faktor-faktor lingkungan sebagai yang harus dijaga.

\section{Hakikat Hubungan Manusia dengan Alam} Sekitar

Hakikat hubungan manusia dengan alam sekitar pada kegiatan tanam padi di Kampung Adat Cikondang, tergambar dari tiga pandangan yang terjadi yaitu pandangan tradisional, transisi dan moderen.

Pandangan yang menyatakan bahwa hidup itu harus tunduk kepada alam artinya menerima apa adanya terhadap apa yang terjadi. Kegiatan tanam padi yang berakhir pada panen padi dengan dua peluang yang bisa terjadi apakah panen berhasil, artinya sesuai dengan yang diharapkan atau apakah panen tidak berhasil, artinya panen tidak sesuai dengan yang diharapkan. Ketika panen tidak sesuai dengan yang diharapkan, maka masyarakat harus menyadari dan harus merelakan hasil ini, karena apa yang terjadi pada hasil panen, hakikatnya adalah rizki yang telah diberikan Tuhan kepada makhluknya. Masyarakat sebagai makhluk, harus menerima pemberian tersebut apa adanya. Inilah bentuk nilai kepasrahan dan keridloan dari masyarakat sebagai makhluk terhadap Sang Pencipta yang telah memberikan rizki tersebut.

Sementara pandangan yang menyatakan bahwa hidup itu harus selaras dengan alam, artinya alam memberikan pilihan-pilihan waktu yang baik bagi makhluknya. Maka gunakanlah waktu tersebut sebagai pilihan terbaiknya di dalam melakukan aktivitasnya. Tanam padi pada masyarakat Kampung Adat Cikondang, khususnya pada waktu tabur benih dan tanam padi, sangat memperhatikan kondisi alam, pada aspek kondisi angin dan hujan, karena kondisi ini akan sangat menentukan ke depannya yang berdampak pada keberhasilan tanam padi, saat panen 
tiba. Masyarakat Kampung Adat Dikondang, telah menjadikan alam sebagai acuan dalam prosesi tanam padi, dengan harapan alam dapat memberikan hasil terbaik ketika panen padi tiba.

Sedikit berbeda dengan masyarakat yang berpandangan bahwa manusia hidup harus menguasai alam, sehingga manusia harus memiliki ilmu untuk mengantisipasi apa yang akan terjadi bisa sifatnya antisipasi atau bagaimana mengembangkan hasil produksi yang maksimal, kalaupun kondisi alam kurang mendukung. Masyarakat Kampung Adat Cikondang, telah berhasil dalam pengembangan ilmu pengetahuan pada aspek tanam padi, dengan tidak menggunakan faktor-faktor eksternal, seperti penggunaan teknologi traktor, pestisida, dan sejenisnya. Terhindarnya masyarakat dari penggunaan pestisida dengan tujuan untuk menjaga keseimbangan ekosistem, karena terjaganya ekosistem, maka terjaganya hasil panen yang maksimal. Tingginya tingkat pengetahuan masyarakat Kampung Adat Cikondang dalam hal budaya tanam padi, merupakan wujud dari tumbuhnya keyakinan masyarakat terhadap pentingnya menjaga keseimbangan alam. Jadi, tingkat pengetahuan masyarakat ini adalah lebih kepada bagaimana memahami perilaku alam, yang dijadikan acuan waktu, kapan tanam padi dilakukan Hakikat Kedudukan Manusia dalam Ruang dan Waktu

Hakikat kedudukan manusia dalam ruang dan waktu dalam budaya tanam padi di Kampung Adat Cikondang, tergambar dari tiga pandangan berikut.

Pandangan bahwa manusia hidup harus berorientasi ke masa lalu, yang dapat dijadikan standar kebijakan yang harus dilakukan kepada generasi berikutnya. Tanam padi adalah aktivitas masyarakat pada menanam benih, menanam padi, memanen padi, yang telah terjadi dalam waktu yang sangat lama, secara turun temurun. Keberlangsungan suatu kegiatan tanam padi dengan tetap menjaga nilai-nilai luhur sebagai pijakan masyarakat, berarti bahwa masyarakat Kampung Adat Cikondang menjadikan masa lalu sebagai acuan perilaku dalam tanam padi saat ini. Masyarakat sangat memperhatikan nilai-nilai yang berlaku dalam budaya tanam padi, karena masyarakat meyakini bahwa tidak ada acuan lain yang lebih baik yang bisa menggantikan dalam kegiatan tanam padi di Kampung Adat Cikondang.

Pandangan lain yang menguatkan pola kedudukan manusia dengan ruang dan waktu bahwa manusia hidup harus berorientasi pada masa kini, artinya keputusan yang harus diambil atas dasar kepentingan saat ini. Kegiatan tanam padi pada masyarakat Kampung Adat Cikondang sampai saat ini, difahami oleh masyarakatnya merupakan kegiatan yang sangat penting, harus dipertahankan sehingga harus dilakukan secara turun temurun. Pandangan ini mengaburkan pandangan bahwa budaya tanam padi tidak produktif, karena tidak bisa meningkatkan kesejahteraan masyarakatnya. Kepentingan saat ini pada masyarakat Kampung Adat Cikondang adalah bagaimana melestarikan nilai-nilai yang terkandung dalam prosesi tanam padi, karena telah dapat menjaga keseimbangan dalam hubungan antara sesama manusia dan antara manusia dengan alam sekitar. Buktinya bahwa prosesi tanam padi yang telah berlangsung kurang lebih selama 300 tahun, tetap terjaga bahkan justru telah menjadi bagian penting bagi masyarakat di luar Kampung Adat Cikondang, yang mengaguminya.

Sementara pandangan bahwa menusia hidup harus berorientasi ke masa depan, artinya bahwa keputusan yang diambil atas dasar kepentingan masyarakat yang akan hidup di masa yang akan datang, melengkapi pandangan bahwa manusia harus menjadikan masa lalu sebagai pengalaman, masa sekarang untuk melihat fenomena masyarakat, dan melihat ke depan untuk memberikan kesempatan kepada generasi berikutnya di dalam pemanfaatan ruang kehidupan ini. Masyarakat Kampung Adat Cikondang dalam prosesi tanam padi, selalu melihat jauh ke depan tentang apa manfaat yang akan diberikan pada generasi berikutnya. Prosesi tanam padi telah 
berlansung sangat lama, yaitu sekitar 300 tahun, ini artinya bahwa masyarakat Kampung Adat Cikondang saat ini merupakan masyarakat yang tetap merasakan pentingnya budaya tanam padi. Nilai-nilai yang terkandung di dalamnya dijadikan Hakikat hubungan manusia dengan karya dan beramal dalam kegiatan tanam padi di Kampung Adat Cikondang, digambarkan sebagai berikut.

Pandangan bahwa hidup manusia atas dasar keberlangsungan hidup, artinya melakukan sesuatu supaya bisa atau tetap hidup. Padi hasil panen pada budaya tanam padi di Kampung Adat Cikondang tidak diperjualbelikan, artinya hasil panen ini hanya digunakan untuk konsumsi masyarakat adat Cikondang saat berlangsungnya prosesi tanam padi berikutnya. Artinya bahwa masyarakat memaknai padi hasil panen, sebagai sarana supaya kegiatan tanam padi berikutnya bisa tetap dilaksanakan, sebagai bagian dari upaya melestarikan budaya.

Pandangan bahwa hidup manusia didasarkan pada kedudukan atau kehormatan, artinya hidup itu untuk mendapatkan penghargaan dari orang-orang sekitar. Budaya tanam padi yang telah berlangsung lama ini dengan tetap menjaga budaya leluhur sebagai pedoman pelaksanaan tanam padi, seperti penggunaan aspek waktu, tunduk mentaati pimpinan, menjunjung tinggi nilai-nilai kebersamaan, gotong royong, kerjasama, sukarela, menjunjung tinggi kepentingan bersama telah diyakini bersama masyarakat Kampung Adat Cikondang untuk dilaksanakan dengan penuh kesungguhan. Hal ini menjadi jelas bahwa budaya tanam padi ini, dengan sendirinya memberikan pemahaman kepada orang lain Hakikat hubungan manusia dengan manusia lain dalam prosesi tanam padi di Kampung Adat Cikondang, tergambar berikut ini.

Pandangan bahwa hidup manusia memiliki hubungan vertikal, artinya hidup berorientasi ke atas yang menggambarkan senioritas. Kegiatan tanam padi merupakan suatu aktivitas bersama dengan rentetan waktu yang lama dan dengan tahapan kegiatan yang panjang. Lamanya waktu dan banyaknya kegiatan disamping banyaknya materi serta sebagai acuan, yang berlangsung secara turun temurun untuk menjaga dan memberikan kesempatan kepada generasi berikutnya.

Hakikat Hubungan Manusia dengan Karya dan Beramal

tentang adanya nilai-nilai luhur sebagai warisan nenek moyangnya yang sangat menghormati kepentingan bersama, menjaga kepentingan generasi yang akan datang, melestarikan alam, dan nilai-nilai sosial di masyarakat akan sangat dihargai oleh orang lain. Atas dasar hal tersebut maka dengan sendirinya masyarakat pendatang memberikan penghormatan dan memberikan penghargaan kepada masyarakat Adat Cikondang ini, sebagai masyarakat yang tumbuh dan berkembang mengutamakan nilai-nilai budaya dan sosial sebagai acuan masyarakat di dalam berperilaku.

Pandangan bahwa hidup manusia didasarkan pada bagaimana bisa berkarya dan beramal sehingga dapat menolong orang lain yang kurang beruntung. Budaya tanam padi dengan rentetan prosesi yang dijalankannya, sangat memperhatikan kepentingan orang lain, artinya menghormati dan menghargai orang lain. Ini menggambarkan bahwa hakikat budaya tanam padi adalah untuk membantu orang lain, paling tidak saat berlangsungnya prosesi tanam padi, dalam bentuk sajian makanan yang bisa dinikmati oleh siapapun yang terlibat dalam upacara dan sebaliknya masyarakat yang terlibat berkarya dalam bentuk berpartisipasi mensukseskan kegiatan tanam padi tanpa harus dibayar.

Hakikat Hubungan Manusia dengan Manusia Lain

banyaknya personil yang dibutuhkan, akan berkaitan dengan pentingnya seorang pemimpinan untuk keberlangsungan upacara tanam padi. Seorang pemimpin yang mumpuni tentunya berkaitan dengan pengalaman yang dimilikinya, hal ini akan berkaitan dengan tingkat senioritas usia di masyarakat. Maka lahirlan seorang pemimpin dalam setiap kegiatan proses tanam padi, yang mengarahkan proses tanam padi sampai proses panen padi. Masyarakat menaati 
perintah pimpinan dalam setiap prosesi tanam padi, karena pimpinan yang senior ini dianggap sebagai warisan nenek moyang yang memiliki pengetahuan, keterampilan dan pengalaman untuk keberhasilan tanam padi.

Pandangan lain adalah bahwa hidup manusia harus bersifat horizontal atau kolekial, artinya bahwa hidup membutuhkan orang lain, sehingga tumbuh sikap gotong royong dan saling membantu. Kegiatan tanam padi di Kampung Adat Cikondang penuh dengan nilai-nilai budaya. Nilai budaya yang terlihat jelas adalah nilai gotong royong, kerjasama, saling menghargai, menghormati dan saling membantu. Prosesi tanam padi adalah proses menanam padi yang dilakukan oleh banyak orang dengan tugas yang melekat pada masing-masing orang yang akan menanam padi. Hal ini menjelaskan bahwa masingmasing orang harus saling menghargai dan menghormati atas tugas orang lain, sehingga akan tumbuh saling membantu, bekerjasama yang tumbuh dalam budaya gotong royong. Inilah yang tumbuh dan berkembang pada Nilai budaya tanam padi di Kampung Adat Cikondang Kabupaten Bandung, tercermin dari keunikannya. Hal ini ditunjukkan melalui prasyarat yang harus selalu menjadi bagian utama yang harus dilakukan yaitu ritual-ritual dan upacara sebelum kegiatan tanam padi. Ritual-ritual dalam rangkaian upacara ini sudah jarang ditemukan di daerah lain khususnya di Jawa Barat. Pelibatan wisatawan dalam setiap prosesi tanam padi, juga menjadi hal yang menarik, yang tidak ditemukan di tempat lain. Hal lain adalah kelangkaan, dapat dilihat dari penggunaan alat-alat yang digunakan seperti lisung, cangkul, batang pohong pisang. Alat-alat ini terbilang sudah tidak digunakan saat ini pada kegiatan tanam padi di tempat lain, namun di Kampung Adat Cikondang, masih berlaku dan menjadi alat utama tanam padi. Daya tarik yang lain adalah keaslian yang ditunjukkan melalui keaslian proses tanpa menggunakan teknologi modern dan tanpa pestisida yang dapat merusak lingkungan. Kegiatan tanam padi di Kampung Adat Cikondang, dari awal sampai berakhirnya masyarakat Kampung Adat Cikondang sebagai wujud hubungan horizontal antara manusia yang satu dengan manusia yang lain.

Pandangan lainnya adalah bahwa hidup manusia bersifat individual, artinya setiap manusia dituntut untuk menunjukkan prestasi atas apa yang telah dilakukannya. Tumbuhnya kerjasama, gotong royong, saling menghormati dan menghargai diantara orang-orang yang ikut berpartisipasi pada prosesi tanam padi adalah syarat tercapainya keberhasilan dalam tanam padi pada fase akhir panen padi. Namun, masing-masing orang dituntut untuk dapat menunjukkan prestasinya yang maksimal, sehingga akan memberikan motivasi bagi orang lain dalam memberikan keberhasilan. Hal inilah gambaran bahwa manusia dituntut harus dapat hidup secara individu, disaat masingmasing individu ini dapat memberikan upaya sampai pada hasil terbaik bagi anggota lainnya.

\section{Nilai Budaya Tanam Padi sebagai Daya Tarik Wisata}

kegiatan, selalu menjaga kebersihan baik kebersihan lahir maupun kebersihan batin. Kebersihan lahir ditunjukkan melalui tuntutan kebersihan terhadap setiap orang yang terlibat dan tempat. Sementara kebersihan batin, adalah tumbuhnya keyakinan bahwa kegiatan ini semata hanya untuk mengabdi kepada Yang Maha Kuasa, tidak adanya rasa iri hati, benci, malas, dan penyakit-penyakit hati yang lain. Disamping kebersihan juga keamanan, bahwa setiap orang yang terlibat terjamin dengan keamanannya, artinya mereka terhindar dari ancaman orang lain, binatang maupun keamanan tempat yang digunakan.

Keunikan, kemenarikan, kelangkaan, keaslian, kebersihan dan keamanan merupakan faktor penting dalam keberlangsungan kegiatan tanam padi di Kampung Adat Cikondang, disamping menjadi faktor pendorong kehadiran wisatawan (Syarifuddin, 2020). Sementara keenam faktor pendukung daya tarik wisata ini ditambah dengan keindahan dan nilai keanekaragaman budaya akan menjadi 
sasaran atau tujuan kunjungan wisata (Undang-Undang Republik Indonesia, Tentang Kepariwisataan, Nomor 10, 2009). Hal senada disampaikan olehWarfani Suwardjokjo, (2007) bahwa faktor-faktor pendukung daya tarik wisata ini juga akan menjadi pemicu kunjungan wisatawan ke destinasi tersebut. Sementara Zaenuri, (2012) menitikberatkan pada aspek bahwa faktorfaktor pendukung daya tarik wisata akan menjadi menarik bagi wisatawan untuk dilihat dan dinikmati serta memiliki nilai kelayakan untuk dijual di pasar wisata.

Budaya tanam padi di Kampung Adat Cikondang yang dibangun atas dasar rangkaian kegiatan tabur benih, mencangkul, tanam padi, panen pade, dan tumbuk padi memiliki nilai daya tarik wisata, yang dapat mendorong wisatawan untuk berkunjung dan menikmati bahkan berpartisipasi dalam prosesi tanam padi.

\section{SIMPULAN}

Mengacu pada pembahasan yang telah disampaikan pada bab pembahasan, maka dapat diambil kesimpulan dan saran, sebagai berikut: (1) Kegiatan tanam padi pada masyarakat Kampung Adat Cikondang sarat dengan nilai budaya yang terkandung di dalamnya. Nilai hakikat manusia bahwa hidup manusia adalah anugrah Tuhan Yang Maha Kuasa yang harus diterima dan disyukuri. Nilai hakikat hubungan manusia dengan alam sekitar bahwa hidup manusia pada satu waktu harus tunduk pada alam, harus selaras dengan alam, bahkan harus menguasai alam melalui ilmu pengetahuan. Nilai hakikat kedudukan manusia dalam ruang dan waktu bahwa hidup manusia harus menjadikan masa lalu sebagai pelajaran, masa kini yang harus diupayakan, dan masa depan harus direncanakan. Nilai hakikat hubungan manusia dengan karya dan beramal bahwa manusia harus dapat mempertahankan hidupnya, harus patuh terhadap budaya leluhur dan harus dapat bermanfaat bagi kehidupan manusia yang lain. Nilai hubungan manusia dengan manusia lain bahwa hidup manusia dibangun melalui hubungan vertikal, artinya tumbuh dan berkembang atas dasar bimbingan orang tua, hubungan horizontal, harus berdampingan dengan orang lain, individual, harus tumbuh dan berkembang menunjukkan prestasi yang maksimal; (2) Kegiatan tanam padi pada masyarakat Kampung Adat Cikondang sebagai daya tarik wisata. Hal ini dapat dilihat dari keunikannya berupa ritual dan upacara sebelum kegiatan tanam padi. Hal lain adalah pelibatan wisatawan dalam prosesi tanam padi, sebagai aspek yang menarik, dengan penggunaan alat-alat tradisional yang sudah langka digunakan di tempat lain, dan terhindarnya dari penggunaan teknologi modern dan pestisida yang dapat merusak lingkungan, sebagai wujud kekhasan dan keaslian, disamping menjaga kebersihan dalam persiapan, proses dan hasil juga aspek keamanan, supaya terhindar dari ancaman orang lain, binatang maupun keamanan tempat yang digunakan.

Saran dalam penelitian ini adalah (1) Tingginya nilai budaya tanam padi pada masyarakat Kampung Adat Cikondang dengan daya tarik wisata yang tercermin dari tingginya penghargaan wisatawan terhadap budaya tanam padi, maka pelaku prosesi tanam padi harus dapat memberikan pemahaman kepada generasi muda untuk dapat berperan aktif dalam melestarikan budaya ini. Hal yang dapat dilakukan adalah dibuat wadah kegiatan yang melibatkan unsur pelaku prosesi tanam padi dan para pemuda untuk dapat berdiskusi mengenai pentingnya melestarikan budaya leluhur, karena memiliki nilai yang luhur; (2) Pemerintah dapat membuat kebijakan mengenai pelestarian budaya tanam padi di Kampung Adat Cikondang serta pemberian stimulus dana sebagai motivasi serta semangat bagi masyarakat dalam pelaksanaan kegiatan tanam padi di Kampung Adat Cikondang. 


\section{REFERENSI}

C. Kluckhohn. (1954). The Concept of Culture. The Science of Men in The World Crisis. (R. L. Editor, Ed.). New York: Columbia University Press.

Dinas Pertanian Tanaman Pangan. (2011).

Huberman, M. dan. (1984). Penelitian Kualitatif dan Kuantitatif. Yogyakarta: Kanisius.

Kartawisastra, H. U. (1980). Strategi Klasifikasi Nilai. Jakarta, P3G Depdikbud.

Maarif, S. (2007). Revitalisasi Pendidikan Islam (h. 114). Yogyakarta: Graha Ilmu.

Nafila, O. (2013). Peran Komunitas Kreatif dalam Pengembangan Pariwisata Budaya di Situs Megalitikum Gunung Padang. Journal of Regional and City Planning, 24(1), 65-80.

Prasodjo, T. (2017). Pengembangan Pariwisata Budaya dalam Perspektif Pelayanan Publik. Jurnal Office, 3(1), 7. https://doi.org/10.26858/jo.v3i1.3448

Purwadarminta, W. J. S. (1999). Kamus Umum Bahasa Indonesia.

Rakyat, P. (2020). Tajuk Rencana, Petani Sejahtera.

Ridho, S. D. F. (2014). Diajukan kepada Fakultas Dakwah dan Komunikasi Universitas Islam Negeri Sunan Kalijaga Yogyakarta untuk Memenuhi Sebagian Syarat-syarat Memperoleh Gelar Sarjana Strata I. Teknik Sinematografi Dalam Melukiskan Figur K.H. Ahmad Dahlan (Studi Deskriptif Pada Film Sang Pencerah), 2-129.

Solihat, K. (2020). Petani Tak Diproteksi,
Kedaulatan Pangan Hanya Mimpi, Pikiran Rakyat, Senin, 19 Oktober 2020.

Suwardjokjo, W. (2007). Pariwisata Dalam Tata Ruang Wilayah. Bandung, ITB.

Syarifuddin, D. (2015). Daya Tarik Wisata Upacara Tradisional Hajat Laut Sebagai Nilai Budaya Masyarakat Batu Karas. Daya Tarik Wisata Upacara Tradisional Hajat Laut Sebagai Nilai Budaya Masyarakat Batu Karas, 12(1), 100-110.

https://doi.org/10.17509/jurel.v12i1.10 50

Syarifuddin, D. (2017). Nilai Wisata Budaya Seni Pertunjukan Saung Angklung Udjo Kota Bandung, Jawa Barat, Indonesia. Nilai Wisata Budaya Seni Pertunjukan Saung Angklung Udjo Kota Bandung, Jawa Barat, Indonesia, 13(2), 53-60.

https://doi.org/10.17509/jurel.v13i2.49 79

Syarifuddin, D. (2020). Value of Tourist Attraction in Villa Kancil, 08(01), 3141. Retrieved from http://journal.uinsgd.ac.id / index.php/ijni/article/view/8782

Syarifuddin, D., \& Priyanto, R. (2019). Membangun fasilitas, membangun minat kunjungan ulang.

Thoha, M. C. (1996). Kapita Selekta Pendidikan Islam. Yogyakarta: Pustaka Pelajar.

Undang-Undang Republik Indonesia, Tentang Kepariwisataan. (2009).

Zaenuri, M. (2012). Perencanaan Strategis Kepariwisataan Daerah, Konsep dan Aplikasi. Jogjakarta: e-Gov Publishing. 